\title{
Occitan Language
}

National Cancer Institute

\section{Source}

National Cancer Institute. Occitan Language. NCI Thesaurus. Code C154067.

A Romance language spoken in southern France, Italy's Occitan Valleys, Monaco, and Spain's Val d'Aran. 